\title{
Some Aspects of Acute Pulmonary Edema with Special Reference to Pulmonary Hemodynamics
}

\author{
Soroku SAITOH, M.D., ${ }^{*}$ Yasuhiro Kinoshita, M.D., Yoshitaka \\ Tokumasa, M.D., Yasushi Nakamura, M.D., Masahisa \\ Usami, M.D., and Nobutaka DobA, M.D.
}

\begin{abstract}
DULMONARY edema has been produced by various agents and methods in experimental animals. ${ }^{1-7)}$ Of particular importance to hemodynamic research is the consistent production of an acute pulmonary edema in a fairly large animal ${ }^{4)}$ which will facilitate necessary determinations. The present report attempts to elucidate some hemodynamic aspects and importance of blood pressure regulation in the development of acute pulmonary edema in the dog.
\end{abstract}

\section{Methods}

Ten adult mongrel dogs weighing 9 to $20 \mathrm{Kg}$. were anesthetized with intravenous pentobarbital sodium ( $25 \mathrm{mg} . / \mathrm{Kg}$.). Under positive pressure respiration with 95 per cent oxygen and 5 per cent carbon dioxide, thoracotomy was performed at the fourth left intercostal space. The left pulmonary arterial (PA), pulmonary venous (PV) and left atrial (LA) pressures were determined as previously reported. ${ }^{7}$ The right ventricular pressure was obtained by a No. 8 catheter introduced through the right external jugular vein. The femoral arterial blood pressure was obtained by a polyvinyl catheter.

Epinephrine $(0.5,0.75$, or $1.0 \mathrm{mg} . / \mathrm{Kg}$.) plus $2,500 \mathrm{ml}$. of normal saline solution $\left(38^{\circ} \mathrm{C}\right)$ was infused at various rates at an infusion pressure of $100 \mathrm{~mm}$. $\mathrm{Hg}$ into the femoral vein regardless of the dose of epinephrine applied, 4/7 of the total dose of epinephrine was always mixed with the first $1,000 \mathrm{ml}$. of normal saline solution while $3 / 7$ was mixed with the remaining $1,500 \mathrm{ml}$. of the solution.

Immediately after completion of the infusion, the lungs and heart were removed and examined grossly to determine the grade of pulmonary edema. ${ }^{8)}$ Fixed specimens of the lungs and the heart were stained with hematoxylin-eosin and periodic acid-Schiff techniques.

\section{RESULTS}

(1) Dose of epinephrine, infusion rate, lungs/body weight index and Chiba.

From the Second Clinical Department of Internal Medicine, Chiba University School of Medicine,

* Professor of Medicine. 
Table I. Pulmonary Edema in Dogs

\begin{tabular}{|c|c|c|c|c|c|c|c|}
\hline $\begin{array}{l}\text { Dog } \\
\text { No. }\end{array}$ & $\begin{array}{c}\text { Body } \\
\text { Weight (Kg.) } \\
\text { and Sex }\end{array}$ & $\begin{array}{c}\text { Lung } \\
\text { Weight } \\
\text { (Gm.) }\end{array}$ & $\begin{array}{c}\text { Heart } \\
\text { Weight } \\
\text { (Gm.) }\end{array}$ & $\begin{array}{l}\text { Epinephrine } \\
\mathrm{mg} \cdot / \mathrm{Kg} \text {. }\end{array}$ & $\begin{array}{c}\text { Saline } \\
\text { Solution } \\
\mathrm{ml} / \mathrm{Kg} / \mathrm{min} \text {. }\end{array}$ & $\begin{array}{l}\text { Lungs/Body } \\
\text { Weight } \\
\text { Index }\end{array}$ & $\begin{array}{c}\text { Grade of } \\
\text { Pulmonary } \\
\text { Edema }\end{array}$ \\
\hline 1 & $9.0 \sigma^{2}$ & 265 & 90 & 0.5 & 4.22 & 2.94 & 4 \\
\hline 2 & 9.0 우 & 196 & 83 & 0.5 & 4.54 & 2.18 & 4 \\
\hline 3 & 11.0 우 & 193 & 117 & 0.5 & 3.24 & 1.75 & 2 \\
\hline 4 & $14.0 \delta$ & 168 & 110 & 0.5 & 2.96 & 1.20 & 1 \\
\hline 5 & 9.5 우 & 273 & 90 & 0.75 & 4.38 & 2.87 & 4 \\
\hline 6 & $9.5 \delta^{A}$ & 190 & 98 & 0.75 & 4.33 & 2.00 & 3 \\
\hline 7 & 12.59 & 166 & 128 & 0.75 & 2.40 & 1.32 & 2 \\
\hline 8 & $20.0 \%$ & 394 & 251 & 1.0 & 1.56 & 1.97 & 1 \\
\hline 9 & 9.0 우 & 130 & 78 & 1.0 & 5.58 & 1.44 & V.F. 1 \\
\hline 10 & $12.0 \AA$ & 135 & 111 & 1.0 & 3.88 & 1.12 & V.F. 1 \\
\hline
\end{tabular}

V.F. means ventricular fibrillation.

grade of pulmonary edema (Tab. I)

0.5 or $0.75 \mathrm{mg} . / \mathrm{Kg}$. of epinephrine produced severe (grade 4) pulmonary edema. Dog No. 1 died before the end of the infusion. $1.0 \mathrm{mg} / \mathrm{Kg}$. of epinephrine caused ventricular fibrillation and early death in 2 of 3 dogs.

Severe pulmonary edema occurred at an infusion rate of 4.22 and $4.54 \mathrm{ml}$./ $\mathrm{Kg}$. $/ \mathrm{min}$. with $0.5 \mathrm{mg} . / \mathrm{Kg}$. of epinephrine, or at an infusion rate of 4.33 and $4.38 \mathrm{ml} . / \mathrm{Kg} . / \mathrm{min}$. with $0.75 \mathrm{mg} \cdot / \mathrm{Kg}$. of epinephrine. Ventricular fibrillation occurred even at an infusion rate of $3.88 \mathrm{ml} / \mathrm{Kg} . / \mathrm{min}$. with $1.0 \mathrm{mg} . / \mathrm{Kg}$. of epinephrine. A slower infusion rate of $1.56 \mathrm{ml} / \mathrm{Kg} . / \mathrm{min}$. with $1.0 \mathrm{mg} . / \mathrm{Kg}$. of epinephrine produced grade 1 pulmonary edema.

These results demonstrated that an infusion rate of 4 to $5 \mathrm{ml} . / \mathrm{Kg} . / \mathrm{min}$. of saline solution containing 0.5 to $0.75 \mathrm{mg}$. $/ \mathrm{Kg}$. of epinephrine (Fig. 1) is required to produce severe pulmonary edema in dogs.

Hemodynamic observation was carried out on the following 2 groups of dogs in the absence of ventricular fibrillation.

Group I: severe pulmonary edema in which the lungs/body weight index was greater than or equal to 2.0 .

Group II: slight pulmonary edema in which the lungs/body weight index was less than 2.0.

(2) Pulmonary arterial pressure

The mean pulmonary arterial pressure (PAm) was raised to 32 to $75 \mathrm{~mm}$. $\mathrm{Hg}$ ( 158 to 351 per cent) in both groups after the first $500 \mathrm{ml}$. of the infusion. 


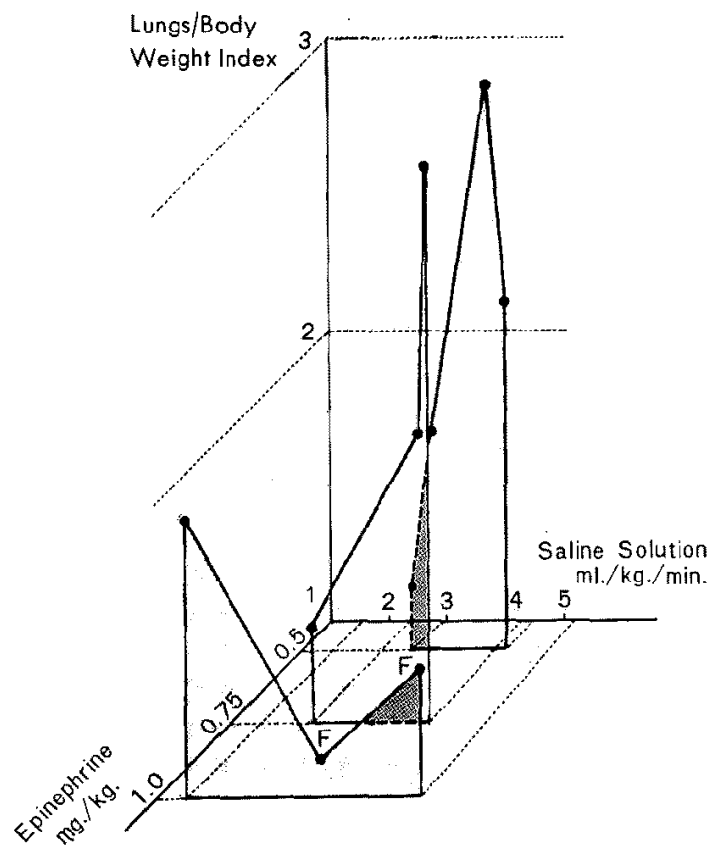

Fig. 1. Interrelationships between the lungs/body weight index, dose of epinephrine and infusion rate. $F$ means ventricular fibrillation.
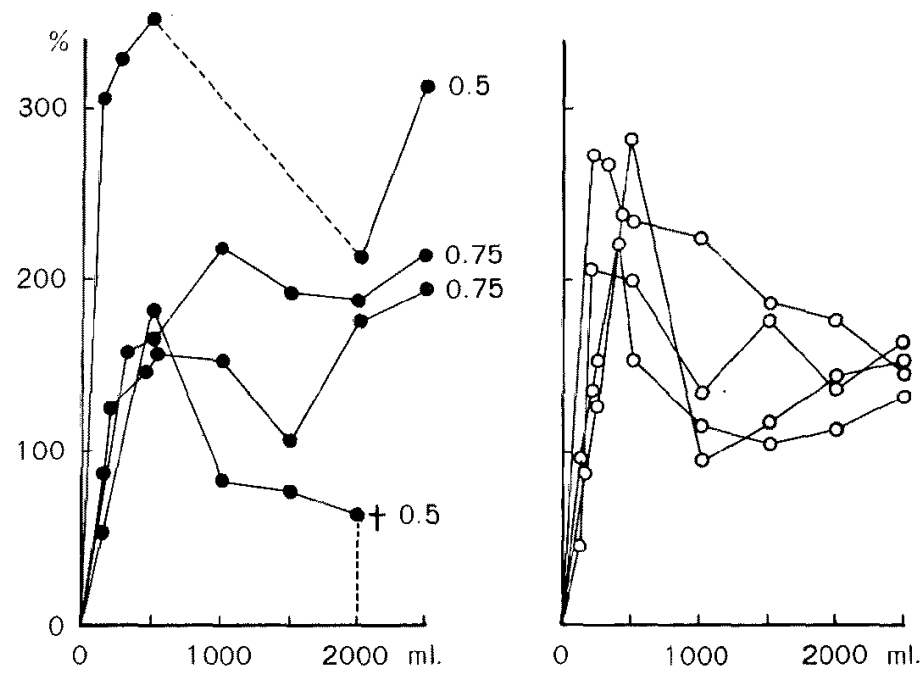

Fig. 2. The ordinate indicates a per cent change in the mean pulmonary arterial pressure. The abscissa shows the volume of the infusion. The solid circle indicates group I and the open circle, group II.

Thereafter, PAm varied rather widely in group I (solid circle) whereas it became less scattered and finally convergent at about 150 per cent in group II (open circle) (Fig. 2). 
(3) Pulmonary venous pressure

The mean pulmonary venous pressure (PVm) was elevated to 20 to $50 \mathrm{~mm} . \mathrm{Hg}$ in both groups at the first $500 \mathrm{ml}$. of the infusion. No marked difference was noted between two groups.

(4) Left atrial pressure

The mean left atrial pressure (LAm) was elevated to 10 to $37 \mathrm{~mm} . \mathrm{Hg}$ in both groups with the first $500 \mathrm{ml}$. of infusion and this remained elevated at $1,000 \mathrm{ml}$. of the infusion.

(5) Pressure gradient between pulmonary artery and left atrium (PAm$\mathrm{LAm})$

This gradient was increased at the time of the first $500 \mathrm{ml}$. of influsion in group I even though the increased pressure gradient remained less than $20 \mathrm{~mm} . \mathrm{Hg}$ in 3 of 4 dogs in this group (Fig. 3).

After infusion of $1,000 \mathrm{ml}$. a decrease in the pressure gradient appeared in all the dogs of group I, with a reversal of the pressure gradient in one dog (Fig. 4). The pressure gradient was below $10 \mathrm{~mm} . \mathrm{Hg}$ in all the dogs and lower than the control value. At the time of $1,500 \mathrm{ml}$. of the infusion, the pressure gradient remained below $10 \mathrm{~mm} . \mathrm{Hg}$ as at $1,000 \mathrm{ml}$. The pressure gradient then varied inconsistently.

In group II (Fig. 5), the pressure gradient was increased over $20 \mathrm{~mm} . \mathrm{Hg}$ in 3 of 4 dogs after the first $500 \mathrm{ml}$. of infusion. A decrease in the pressure

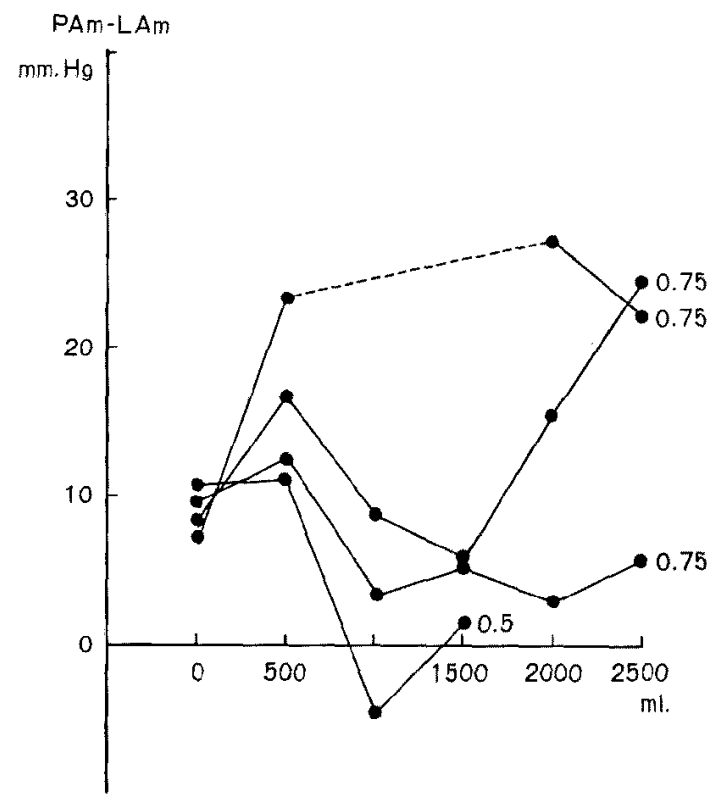

Fig. 3. The solid circle indicates group I. 


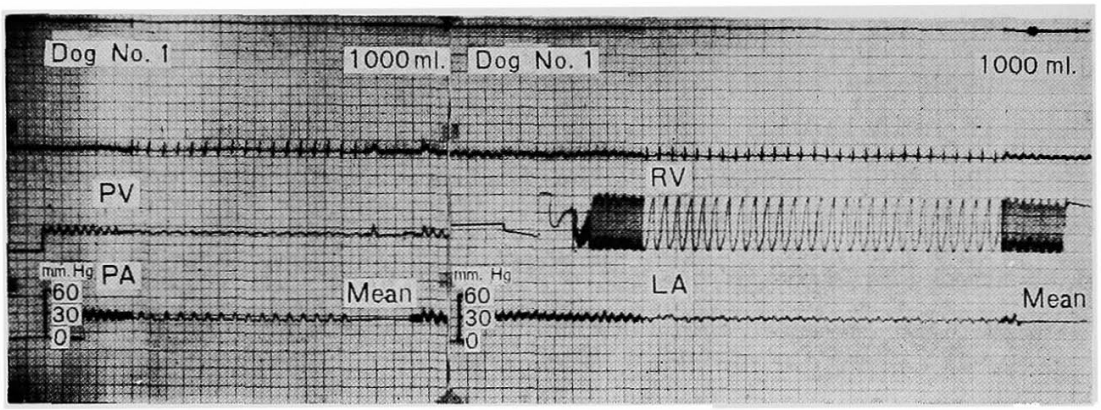

Fig. 4. Reversal of the (PAm-LAm) pressure gradient in dog No. 1 at the time of $1,000 \mathrm{ml}$ of the infusion.

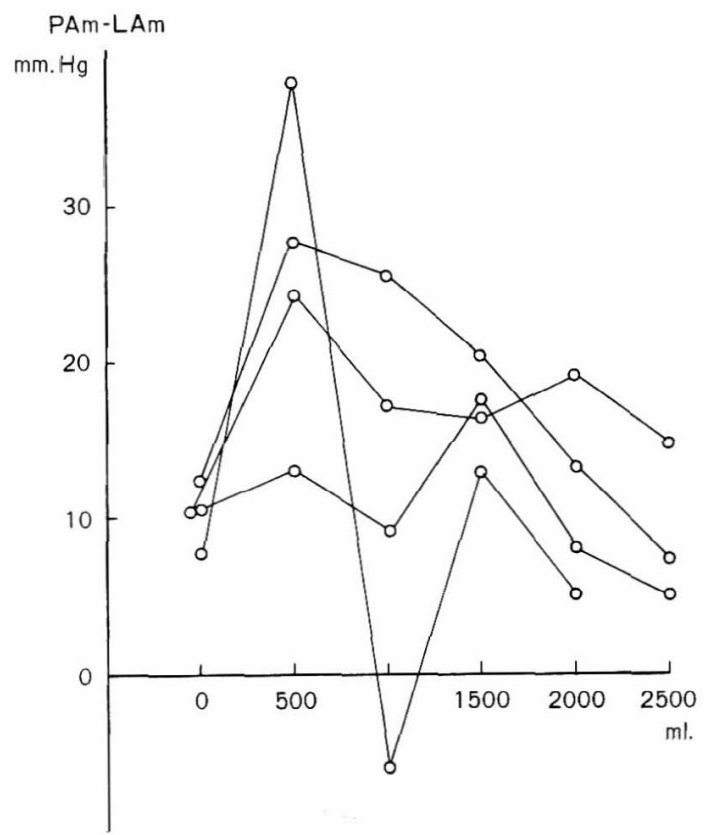

Fig. 5. The open circle indicates group II.

gradient occurred in all the dogs at the time of $1,000 \mathrm{ml}$. of infusion. At the time of $1,500 \mathrm{ml}$. of the infusion, the pressure gradient was larger than $10 \mathrm{~mm} . \mathrm{Hg}$ and higher than the control value. It then converged near the control value.

(6) Pressure gradient between pulmonary artery and vein (PAmPVm)

A decrease in the (PAm-PVm) pressure gradient occurred in 2 of 4 dogs in group I with reversal of the pressure gradient in $1 \mathrm{dog}$, while the decrease also occurred in 1 of 4 dogs in group II at the time of $500 \mathrm{ml}$. of the infusion. 
At the time of $1,000 \mathrm{ml}$. of the infusion, the decrease appeared in 3 of 4 dogs in both groups with a reversal of the pressure gradient in $1 \mathrm{dog}$ in group II.

(7) Pressure gradient between pulmonary vein and left atrium (PVmLAm)

The pressure gradient was all increased in both groups at the time of $500 \mathrm{ml}$. of infusion. A reversal of the pressure gradient was noted in $1 \mathrm{dog}$ of group I at the time of $1,000 \mathrm{ml}$. of infusion.

(8) Right ventricular pressure

The right ventricular end-diastolic pressure was raised progressively during the infusion.

(9) Femoral arterial pressure

The maximal elevation of the femoral arterial pressure appeared prior to $500 \mathrm{ml}$. of the infusion in both groups. It then fell gradually.

(10) Pathoanatomic findings

The lungs were watery and congested. Enormous engorgement of the peribronchial lymphatic vessels was observed as well as moderate hydropericardium.

Microscopic examination revealed a marked edema in perivascular interstitial tissue which extended to peribronchial tissue. The interstitial tissues were filled with PAS-stained substance (Fig. 6, 7). Slight opaque coagulations, swollen cells and fibers were observed in the alveoli. A few red blood cells were also found in the alveoli in association with pulmonary vascular congestion.

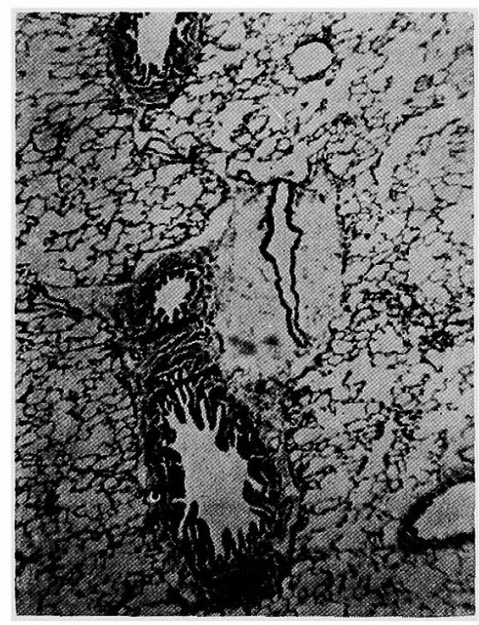

Fig. 6. $\times 25$. 


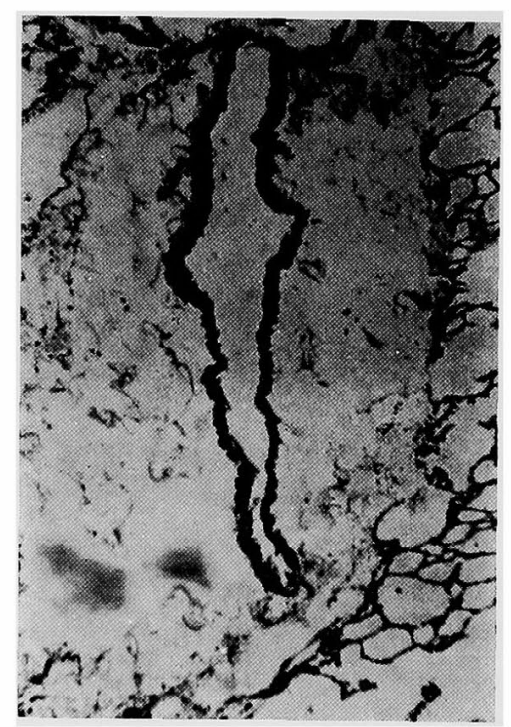

Fig. $7 . \quad \times 75$.

\section{Discussion}

Many reports indicate that a pressure elevation in the pulmonary circuit is an important hemodynamic basis for the production of pulmonary edema. Hamilton et al.9" observed the rise in the pulmonary arterial and venous pressures at exactly the same time and to the same extent with a very large dose of epinephrine. They assumed that this was due to back pressure from the failure of the left ventricle to eject an adequate amount of blood against the high systemic pressure. Haddy et al. ${ }^{3}{ }^{3}$ demonstrated that pulmonary edema in the dog with infusion of normal saline solution is associated with significant elevation in pulmonary venous pressure. They also showed that pulmonary edema does not occur without a rise in pulmonary venous pressure and that the pulmonary vascular pressure gradient, i.e., pulmonary arterial pressure minus the pulmonary venous pressure was significantly less in the group which developed edema.

Luisada ${ }^{10)}$ pointed out that not only periphery-working mechanical factors like narrowing of the vessels, blood pressure elevation, failure of either heart, but also central influences, i.e., functional disturbances of the center were absolutely necessary for occurrence of pulmonary edema with adrenaline in rabbits. Heymans, ${ }^{11)}$ and Heymans and Neil' ${ }^{12)}$ showed that the depressor reflex by the carotid sinus baroreceptors induces changes in heart rate, arterial resistance, venous return and rate of secretion of the adrenal medulla and this depressor mechanism continues to operate during infusion of large doses of adrenaline. 
As seen from the recent studies on homeostasis, control and regulation of blood pressure, ${ }^{13-15)}$ Burton ${ }^{16)}$ stated that essential components of a homeostatic central arterial blood pressure control system operate as a negative "feedback" control system consisting of a specialized sensor, an input loop, the coordinating center (or computer), the output loop (or feedback) and the effector mechanism. These concepts suggest that an impaired function of some component of the control system (e.g., sensor, loop or computer) may result in serious and often irreparable disintegration of the circulation. Thus, pulmonary edema with infusion of epinephrine plus saline solution may develope as a result of an enormous and almost simultaneous pressure rises in the systemic as well as pulmonary circulatory systems which may oppose and overcome various counter-reactions of depressor regulatory mechanisms. Thus sudden onset and persistence of uncontrollable high pressure in the low pressure system can lead to edema. Utilizing our method above described, effects of various drugs on various facets of acute pulmonary edema can be examined. ${ }^{171}$

\section{Summary}

(1) Acute pulmonary edema was produced in dogs by an infusion of 4 to $5 \mathrm{ml} . / \mathrm{Kg} . / \mathrm{min}$. of normal saline solution $(2,500 \mathrm{ml}$.) plus epinephrine $(0.5$ to $0.75 \mathrm{mg} . / \mathrm{Kg})$.

(2) Pulmonary arterial, venous, and left atrial pressures were all elevated with the infusion. These alterations were not restored in acute pulmonary edema.

(3) The (PAm-LAm) pressure gradient was not increased markedly with the start of the infusion. It was then decreased and even became lower than the control value during the infusion. A reversal of the pressure gradient was noted.

(4) Marked edema was found in the perivascular and peribronchial interstitial tissues of the lung.

\section{Acknowledgment}

We wish to express our thanks to Dr. Y. Hayashi, Department of Pathology, Chiba University and Dr. M. Ogawa in our clinic for their advice and assistance. 


\section{References}

1. Visscher, M. B., Haddy, F. J., and Stephens, G.: Pharmacol. Rev. 8: 389, 1956.

2. Luisada, A. A. and Sarnoff, S. J.: Am. Heart J. 31 : 270, 1946.

3. Haddy, F. J., Cambell, G. S., and Visscher, M. B.: Am. J. Physiol. 161: 336, 1950.

4. Jordan, G. L., Jr. and DeLaney, A. Y.: Arch. Surg. 63: 191, 1951.

5. Paine, R., Smith, J. R., Butcher, H. R., and Howard, F. A.: Circulation 5: 759, 1952a.

6. Ferguson, D. J. and Berkas, E. M.: Circulat. Res. 5: 310, 1957.

7. Kinoshita, Y. and Rodbard, S.: Proc. Soc. Exp. Biol. Med. 121: 902, 1966.

8. Singer, D., Hesser, C., Pick, R., and Katz, L. N.: Circulat. Res. 6: 4, 1958.

9. Hamilton, W. F., Woodbury, R. A., and Vogt, E.: Am. J. Physiol. 125: 130, 1939.

10. Luisada, A. A.: Naunyn-Schmiedeberg's Arch. exp. Path. Pharmak. 132: 313, 1928.

11. Heymans, C.: Introduction to the regulation of blood pressure and heart rate. Charles C. Thomas, Springfield, pp. 20-21, 1950.

12. Heymans, C. and Neil, E.: Reflexogenic areas of the cardiovascular system. J. \& A. Churchill, London, p. 41, 1958.

13. Brobeck, J. R.: Exchange, control, and regulation. Yamamoto, W. S., and Brobeck, J. R., Editors: Physiological controls and regulations. Bicentennial volume. Saunders, Philadelphia, pp. 1-13, 1965.

14. Yamamoto, S. W.: Homeostasis, continuity, and fcedback. ibid. pp. 14-31.

15. Peterson, L. H.: Control and regulation of the cardiovascular system. ibid. pp. 308-333.

16. Burton, A. C.: Physiology and biophysics of the circulation. Year Book Medical Publisher, Chicago, pp. 169-202, 1965.

17. Kinoshita, Y., Nakamura, Y., Watanabe, N., Tokumasa, Y., and Inagaki, Y.:Influences of CIBA $31531 \mathrm{Ba}$ on the pulmonary circulation. The 45 th conference of " Respiration and Circulation". March, 1966, Kyoto. 